Poznańskie Studia Teologiczne 30(2016), s. 227-237. doi: $10.14746 /$ pst.2016.30.11

Janusz Królikowski ${ }^{1}$

Uniwersytet Papieski Jana Pawła II w Krakowie

\title{
Niektóre wyzwania pod adresem metody teologii
}

Zagadnienie natury teologii nie cieszy się dzisiaj szczególnym zainteresowaniem teologów, a nawet przestało być przedmiotem osobnej uwagi w ramach programów nauczania teologii. Efektem tego poważnego zaniedbania jest między innymi to, że w rozmaitego typu pracach ćwiczeniowych i dyplomowych od magisterskich po doktorskie, niekiedy nawet na jeszcze wyższym poziomie na temat metody zastosowanej $\mathrm{w}$ pisanej pracy padają najbardziej kuriozalne stwierdzenia, które z metodą teologii nie mają nic wspólnego. Niektórzy piszący, nie wiedząc niczego pewnego o metodzie teologii, zagadnienie to skrzętnie omijają. Zachodzi więc pilna potrzeba szerszego i nowoczesnego zajęcia się tą kwestią. Jest to konieczne $z$ dwóch zasadniczych powodów: po pierwsze, tylko po przedstawieniu metody teologii będzie można obronić jej specyfikę jako nauki, na czym teologom ze słusznych powodów bardzo zależy; po drugie, na gruncie tej refleksji będzie można pokazać, że teologia jest równoprawną nauką pośród innych nauk, mogącą czerpać z ich badań i osiągnięć, a zarazem mogącą także wnosić swój wkład do badań naukowych prowadzonych w innych dziedzinach. Ta druga kwestia jest tym ważniejsza, że na drodze rozporządzeń instytucjonalnych i administracyjnych teologia jest coraz bardziej ,izolowana” od innych dyscyplin naukowych, co może skończyć się jej zupełnym wyrugowaniem z nauki jako takiej, przynajmniej w rozumieniu odpowiedniego ministerstwa. Tymczasem właśnie w ramach teologii zostały wypracowane niektóre kierunki, na przykład nauki o rodzinie, które dzisiaj administracyjnie zostały tak zakwalifikowane, że właściwie odebrano teologii możliwość naukowego wypowiadania się na ten temat. Nie ministerstwo na drodze rozporządzenia powinno określać obszary wiedzy, dziedziny i dyscypliny naukowe, ale powinni to czynić uczeni w ramach swojej działalności, gdyż oni najlepiej rozumieją te problemy, a ich dynamiczne przystosowanie do aktualnych warunków rozwoju wiedzy najlepiej służy jej postępowi, a tym samym człowiekowi.

${ }^{1}$ Ksiądz Janusz Królikowski, dr hab., prof. UPJPII; kapłan diecezji tarnowskiej; od 2014 r. dziekan Wydziału Teologicznego Sekcja w Tarnowie (UPJPII). 
Mając na uwadze wspomniane tutaj fakty, w niniejszym opracowaniu zwracamy uwagę na dwa bardziej szczegółowe zagadnienia, a mianowicie na kwestię kontemplacyjnego charakteru teologii (jest to temat, który dotyczy natury teologii) oraz pytamy się, co inne dyscypliny naukowe - zwłaszcza antropologiczne mogą wnieść do teologii. W tym drugim przypadku chodzi o wskazanie niektórych możliwości interdyscyplinarnego zaangażowania teologii, a tym samym otwarcia także na to, co jest przedmiotem jej badań i na formułowane przez nią propozycje dotyczące zwłaszcza rozumienia człowieka i jego życia w świecie.

\section{Teologia kontemplacyjna}

Słusznie i powszechnie przyjmuje się, że teologia, w takim kształcie jak ją dzisiaj uprawiamy, została zapoczątkowana przez Proslogion seu Alloquium de Dei exsistentia św. Anzelma z Canterbury wraz z tym dziełem, którego stanowi dalszy ciąg, a którym jest De divinitatis essentia Monologium. Te dwa dzieła zostały ogłoszone przez Anzelma pod wspólnym tytułem Fides quaerens intellectum. Tytuł ten dobrze streszcza cały program teologiczny, który został wypracowany w tych dziełach i który odznacza się dużą siłą oddziaływania. Formuła rzeczywiście odniosła wielki sukces i została przyjęta przez większość teologów jako punkt odniesienia prowadzonych badań. Patrząc na wielość sposobów uprawiania teologii, należy jednak zadać pytanie, czy ta łatwa zgoda na formułę nie ukrywa bardzo różnych stanowisk, wśród których są także takie, które stoją daleko od stanowiska zaproponowanego przez Anzelma. W sformułowanym programie Anzelmowi nie chodzi o rozumienie danych objawionych, ale o percepcję intelektualną, sytuującą się między wiarą i wizją beatyficzną (inter fidem et speciem). Zauważmy pewną zuchwałość propozycji Anzelma i kontemplacyjne ukierunkowanie.

Odczytajmy jednak tę wypowiedź w jej kontekście, który Anzelm wyraźnie określił w dedykacji papieżowi Urbanowi II dzieła Liber de fide Trinitatis et de incarnatione Verbi (1098). Napisał tak: „Ponieważ pojmuję rozum, którym jesteśmy obdarzeni, jako pojęcie pośrednie między wiarą (fidem) i wizją beatyficzną (speciem), uważam, że im bardziej się postępuje w rozumie, tym bardziej następuje zbliżenie się do wizji beatyficznej, do której wszyscy dążymy"2. Racjonalne poszukiwanie teologa nie tylko sytuuje się inter fidem et speciem, ale jest ono także ruchem kierującym się do wizji beatyficznej.

Można zasadnie postawić pytanie, czy rzeczywiście takie ukierunkowanie jest obecnie przyjmowane w teologii jako jej pewna wewnętrzna konieczność czy też nie? Bez względu na to, jak by się działo, trzeba przyznać, że takie ukierunkowa-

${ }^{2}$ Anzelm, Liber de fide Trinitatis et de incarnatione Verbi contra blasphemias Ruzelini sive Roscelini, PL 158, 261A. 
nie dobrze odpowiada naturze teologii, będącej nauką opartą na objawieniu Bożym. Objawienie, które jest pierwszą tajemnica, przekraczającą wszystkie inne, manifestującą zamysł zbawienia podjęty przez Boga od wieczności i zrealizowany w Jezusie Chrystusie, jest wydarzeniem transcendentnym, wyrastającym z boskiej inicjatywy - jest wolnym i suwerennym aktem samego Boga. Człowiek nie może wyprowadzić objawienia z siebie samego, a nawet nie może go przewidzieć. Ta interwencja Boga ma charakter całkowicie nowy, przekraczając wszelkie ludzkie oczekiwania. Skoro więc tak mają się rzeczy, teolog powinien mieć zawsze spojrzenie skierowane na manifestację tajemnicy Boga, którą konstytuuje objawienie na tę „samomanifestację Boga w zaufaniu miłości”’. Tym spojrzeniem jest kontemplacja, w której nierozdzielnie łączą się ze sobą rozumienie i adoracja ${ }^{4}$.

Interweniuje w tym miejscu Urząd Nauczycielski Kościoła, na którym spoczywa zadanie komunikowania danych objawienia wspólnocie wierzących, gwarantując ich autentyczność i chroniąc je przed jakimkolwiek skażeniem. Bez interwencji władzy nauczycielskiej Kościoła - która nie polega na niczym innym, jak na wiernym i nieustannym przepowiadaniu Ewangelii Chrystusowej - teologia kontemplacyjna, czyli teologia chcąca sytuować się inter fidem et speciem, byłaby nie do pomyślenia.

Takiemu kontemplacyjnemu ukierunkowaniu teologii przeciwstawiają się obecnie zasadniczo dwa kierunki myślowe i kulturowe. Dominujące dzisiaj propozycje antropologiczne propagują wizję człowieka, która nawet jeśli nie jest ateistyczna, to wyznacza człowiekowi zadania, które nie są zadaniami wyznaczonymi mu w zamyśle Boga Stwórcy i Odkupiciela. Oprócz tego w samym Kościele formułuje się niektóre teorie i programy, które w orędziu chrześcijańskim dają pierwszeństwo zaangażowaniu społecznemu i politycznemu, a tym samym ulega pomniejszeniu człowiek jako chciany przez Boga ze względu na niego samego.

\subsection{Redukcjonizm antropologiczny}

Analizując dzisiejszą problematykę antropologiczną, należy przede wszystkim zwrócić uwagę, że nie jest błędem sam nacisk na problematykę antropologiczną i szerokie zainteresowanie człowiekiem oraz nie on kwestionuje autentyczność teologii. W antropologii jest zawsze coś decydującego dla samego człowieka, a więc i dla teologii. Problemem jest natomiast pewna przesada w formułowanych propozycjach, które czynią z człowieka bożka, kogoś w rodzaju pseudoabsolutu, podczas gdy właściwa dla niego godność sytuuje się w miejscu, wyjątkowym i względnym zarazem, które zajmuje w tajemnicy stworzenia i odkupienia.

\footnotetext{
${ }^{3}$ R. Latourelle, Théologie de la révélation, Paris $1969^{3}$, s. 9-10.

${ }^{4}$ Por. A. Chapelle, À l'école de la théologie, Bruxelles 2013, s. 275-280.
} 
Zainteresowanie teologii człowiekiem jest nieodzowne $\mathrm{z}$ następujących racji.

To dla człowieka i dla jego zbawienia Słowo stało się ciałem. Zbawienie ludzi nie jest efektem drugorzędnym, ,produktem ubocznym” jakiegoś szerszego i ambitniejszego zamysłu Bożego, którego uczestnikiem przypadkowo stał się człowiek. Zagadnienie zbawienia człowieka, tak jak ono się urzeczywistniło, dało wiele do myślenia teologom $\mathrm{w}$ minionych wiekach. Zostały sformułowane najbardziej różnorodne tezy w tej materii, ale ostatecznie zawsze i tak powraca się do istotnych treści objawienia Bożego: „Albowiem Syn Człowieczy przyszedł odszukać i zbawić to, co zginęło" (Łk 19,10). Wcielenie stało się w ten sposób obdarowaniem człowieka. Można postawić pytanie, czy dzisiaj ta prawda wiary wyrażona w Credo zajmuje wystarczające miejsce w teologii, to znaczy czy teologia adekwatnie i szeroko zajmuje się zagadnieniem zbawienia człowieka. Nawiązując do trosk teologicznych ojców Kościoła, można pytać się, czy dzisiejszej teologii zależy na zbawieniu c ałe g o człowieka i każde g o człowieka.

Osoba ludzka ze swej natury nie jest bytem zamkniętym, ograniczonym do swojego własnego świata, ale, przeciwnie, jest otwarta na to wszystko, co istnieje. Rozum i wola człowieka są stworzone dla prawdy i dobra - bez ograniczeń. $\mathrm{W}$ ten sposób tajemnica Boga nieskończonego (z Jego zamysłem zbawienia) odpowiada tej zdolności duchowej człowieka, którą został obdarzony przez Stwórcę i dzięki której może do Stwórcy powracać. Ta zdolność nie jest oczywiście jakimś koniecznym wymogiem, ponieważ człowiek nie ma żadnego prawa do poznania Boga i do uczestniczenia w Jego tajemnicy - jest wewnętrzną zdolnością, którą można odpowiednio wykorzystać. Gdy Bóg urzeczywistnia swój zamysł zbawienia ludzi w Jezusie Chrystusie, czyniąc ich uczestnikami Bożych dóbr, które przekraczają wszelkie rozumienie ze strony ducha ludzkiego ${ }^{5}$, nie niszczy natury ludzkiej, jak burzy się stary i ciasny dom, by zastapić go nowym, większym i pojemniejszym. Bóg daje tylko jakiś dodatek, tak jak rozbudowuje się stary i ciasny dom, na przykład dobudowując dodatkowe piętro. Wraz z manifestacją i komunikacją siebie samego Bóg przychodzi nasycić człowieka i tylko On może to uczynić. „Jedynie Bóg nasyca, i to nieskończenie ponad oczekiwania - Deus solus satiat, et in infinitum excedit", jak wymownie podkreśla św. Tomasz z Akwinu'.

Gdy mówimy o kierunkach myślowych, oddalających myśl chrześcijańską od wymiaru kontemplacyjnego, nie odnosimy się do tych kierunków, które wyrażają zainteresowanie człowiekiem takim, jaki jawi się w świetle tajemnicy stwo-

\footnotetext{
${ }^{5}$ Por. Sobór Watykański II, Konstytucja dogmatyczna o objawieniu Bożym Dei Verbum, w: tenże, Konstytucje, dekrety, deklaracje, Poznań 2002, 6. Por. także J.P. Jossua, Peut-on parler de Dieu?, Genève 2006, s. 29-48.

${ }^{6}$ Tomasz z Akwinu, In Symbolum Apostolorum scilicet «Credo in Deum» expositio, 153, w: S. Thomae Aquinatis Opuscula theologica, vol. 2: De re spirituali, a cura et studio R.M. Spiazzi, Taurini-Romae 1954, s. 217; Katechizm Kościoła katolickiego, Poznań 2002, 1718.
} 
rzenia i odkupienia, ale do tych, którzy izolują człowieka, zamykają go w sobie samym i przypisują mu jaką́s postać samowystarczalności. Według tych kierunków myślowych, które mogą bardzo różnić się między sobą, człowiek nie zajmuje już po prostu swojego miejsca w zamyśle zbawienia, ale staje się jego arbitrem i sędzią. Nie jest już tym człowiekiem, który ulegle przyjmuje objawienie Boże, które jest mu komunikowane, ale staje się jego kryterium i miara, jak zostaje przyjęte w wielu przejawach i propozycjach współczesnego „zwrotu antropologicznego"7.

W dziejach nowożytnych spotykamy wyrażanie się tej opcji antropologicznej w bardzo zróżnicowanych formach. Dla Spinozy (1632-1677), który opowiada się za dogłębną racjonalnością człowieka, treść religii „objawionej” jest racjonalna, chociaż jej forma jest absolutnie irracjonalna. Ukazuje on zwyczajnie, w sposób symboliczny i dostosowany do mentalności potocznej, prawdy filozoficzne dotyczące Boga i człowieka, których zawartość ma ostatecznie charakter moralny i praktyczny.

Kierunek modernistyczny z przełomu XIX i XX wieku uznał natomiast za determinującą ludzką podmiotowość i wewnętrzność. Chrześcijaństwo w tym nurcie myślowym jest ujmowane wyłącznie według tego kryterium. Zarówno protestanci liberalni, jak i moderniści katoliccy zmierzali do oddzielenia poznania religijnego od wszelkich związków z rozumem spekulatywnym. Według Augusta Sabatiera (1839-1901) chrześcijaństwo może uznać za prawdę tylko to, co samo z siebie wykazuje, że jest prawdą. Alfred Loisy (1857-1940) uznaje Biblię za opowiadanie doświadczeń przeżytych przez wierzących w Starym Testamencie i przez pierwszych chrześcijan, a Kościół nie ma innej misji do spełnienia niż wyrazić te indywidualne doświadczenia.

Mentalność człowieka nowożytnego, jak ją pojmuje Rudolf Bultmann (1884-1976), określa kryterium antropologiczne, którym się posługuje. Tematy biblijne, takie jak preegzystencja Jezusa Chrystusa, Jego wcielenie, śmierć odkupieńcza, zmartwychwstanie, Jego wniebowstapienie i powrót na końcu czasu, stanowią część wizji świata, która jest absolutnie nie do przyjęcia przez człowieka współczesnego. Nie może on aktem woli uczynić własną koncepcji, która wykracza poza rzeczywistość, jaka bezpośrednio jawi się jego percepcji.

Według teologii katolickiej człowiek za pośrednictwem Kościoła nawiązuje kontakt z objawieniem jako suwerennym i wolnym aktem Boga. Tam więc, gdzie ulega osłabieniu odniesienie do Urzędu Nauczycielskiego Kościoła lub gdzie go w ogóle brakuje, argument antropologiczny zaczyna dominować i totalitarnie podporządkowuje sobie wszystko. Konsekwencje takiego ujęcia od razu są widoczne w chrystologii, charytologii, liturgii, etyce chrześcijańskiej, duchowości,

\footnotetext{
${ }^{7}$ Por. G. Pattaro, M.C. Bartolomei, A. Gallas, La svolta antropologica. Un momento forte della teologia contemporanea, Bologna 1991.
} 
katechezie, duszpasterstwie. Ostatecznym efektem takiego przewrotu jest to, że już nie człowiek jest „na obraz Boży”, ale Bóg staje się na obraz człowieka. Znajdujemy się wobec nowej i paradoksalnej formy antropomorfizmu, którego konsekwencją jest neopogaństwo.

\subsection{Dominacja praxis}

Drugi kierunek myślowy, mający nastawienie i konsekwencje antykontemplacyjne, daje, niejednokrotnie bezkrytycznie, pierwszeństwo działaniu. W gruncie rzeczy jest on pewnym wariantem wyżej opisanej tendencji antropologicznej. Jest to nowa forma ugięcia się pod wymogami pewnych elementów ideologicznych kultury współczesnej. Według tego kierunku liczy się tylko skuteczność. Teologia otrzymuje swoją celowość za pośrednictwem praxis - ona przyznaje prymat zaangażowaniu. Jego główne zainteresowanie zwraca się do struktur społecznych i instytucji politycznych, zostawiając na boku problemy moralności osobistej. Ten nurt teologiczny wyraźnie różni się od teologii klasycznej, która jest wybrakowana - w ich oczach - ponieważ nie jest właściwie ukierunkowana i zaangażowana po stronie człowieka rozumianego teologicznie w perspektywie zbawienia ${ }^{8}$.

Jest, oczywiście, zadaniem tych, którzy promują taką teologię, uzasadnić to stanowisko, a w sposób szczególny tę praxis, do której stale się odnoszą. Można przyjać praxis jako postulat, ale tylko otwarcie pytając się, w jaki sposób jest ona podatna na głębsze analizy, krytykę, ewentualnie na korektę? Jest jedna czy też przedstawia się pod różnymi formami i różnymi ukierunkowaniami? W świetle jakiego kryterium można dokonać jej uwzględnienia?

W sformułowaniu tych pytań trzeba zobaczyć, że teologie działania społecznego i politycznego biorą na siebie zadanie niemożliwe do wykonania, gdyż dają pierwszeństwo temu zaangażowaniu w stosunku do myślenia. Stają się w ten sposób łatwym łupem modnych ideologii, jeśli nie są już ich bezpośrednią emanacją. Błąd polega na przeciwstawianiu kontemplacji i skuteczności, mimo że już wielokrotnie zostało wykazane, że nie ma skuteczności, która nie wypływałaby z kontemplacji ${ }^{9}$. Nasze spojrzenie na Boga pozwala nam uświadomić sobie, na czym polega zamysł Boży zrealizowany w Jezusie Chrystusie. Ten plan Boży nie tylko wpływa na ubogacenie umysłu, ale jest czynem - działaniem. Wcielenie Syna Bożego, założenie Kościoła i Jego misja zbawcza, głoszenie królestwa Bożego, które jest już tajemniczo obecne w świecie, ale czeka jeszcze na swoje wypełnienie przez Boga na końcu czasu - to wszystko są działania. To działanie jednak nie wyczerpuje się w sobie. Stale i niezmiennie odsyła nas do kontempla-

\footnotetext{
${ }^{8}$ Por. J. Królikowski, Teologia między ortodoksja i ortopraksja, w: Tożsamość teologii, red. A. Anderwald, T. Dola, M. Rusecki, Opole 2010, s. 187-201.

${ }^{9}$ Por. H.U. von Balthasar, Kim jest chrześcijanin?, tłum. F. Wycisk, Paris 1971, s. 74-79.
} 
cji, która wypełni się w uszczęśliwiającym i przemieniającym oglądzie w chwale nieba: „Umiłowani, obecnie jesteśmy dziećmi Bożymi, ale jeszcze się nie ujawniło, czym będziemy. Wiemy, że gdy się objawi, będziemy do Niego podobni, bo ujrzymy Go takim, jakim jest" (1 J 3,2).

Wobec manifestacji tajemnicy zbawienia chrześcijanin nie jest biernym widzem, ale jest aktorem. Wiemy, że znamy Boga, jeśli zachowujemy Jego przykazania. To jest dowód autentyczności chrześcijańskiej według św. Jana (por. 1 J 2,3). Już na samym początku Kościoła zaznaczyła się wśród wierzących obecność niebezpieczeństwa sprowadzenia wiary do czystej spekulacji religijnej (gnoza). Stąd nacisk na ujęcie, według którego wiara powinna obejmować całe ludzkie życie: wewnętrzne i zewnętrzne, osobiste i społeczne. Dlatego w Dziejach Apostolskich często w odniesieniu do postawy chrześcijańskiej stosuje się miano „drogi”. Podkreśla się w ten sposób, że wiara jest opcją intelektualną i działaniową, ukierunkowującą całe ludzkie życie.

Podstawowy wymóg teologów nastawionych na praxis może być w znacznym stopniu podzielany $\mathrm{w}$ ramach teologii kontemplacyjnej. Walka z niesprawiedliwością społeczną i polityczną nie jest obca planowi zbawienia. Chrześcijaństwo nie może tolerować sytuacji, w której człowiek żyje w warunkach uwłaczających jego godności. Tylko jednak w ramach teologii kontemplacyjnej pilny obowiązek pomagania ludziom i dokonywania korekt w instytucjach może zostać usytuowany we właściwym miejscu i znajdzie uzasadnienie przez wskazanie dróg, które nie prowadzą do pogubienia się.

\section{Nauki i teologia}

Gdy mówi się dzisiaj o naukach antropologicznych w ich relacji do wiary, na ogół ma się na myśli następujące dyscypliny: psychologię (łącznie z psychoanaliza), socjologię, etnologię i nauki zajmujące się religią ${ }^{10}$. Niektóre z tych dyscyplin mają nie tylko charakter teoretyczny, lecz także praktyczny, a zatem nie tylko należą do nauki, ale także do ,sztuki”. W przeszłości te dyscypliny były uprawiane przez badaczy obcych w stosunku do wiary, tak że niektóre z nich zostały tak wykorzystane, że stały się elementami ateistycznej wizji świata i egzystencji. W ostatnich dziesięcioleciach te dyscypliny naukowe rozwinęły się opatrznościowo i zwracają ogólną uwagę, wyraźnie pobudzaną także przez sprzymierzone $\mathrm{z}$ nimi środki masowej komunikacji.

Jakie stanowisko powinien zająć teolog wobec tych dyscyplin nauki? Można powiedzieć już na wstępie, że powinno być ono pozytywne i krytyczne zarazem. Powinno być p o z y ty w e, ponieważ te dyscypliny dostarczają teologii, każ-

\footnotetext{
${ }^{10}$ Por. G. Cottier, Les chemins de la raison. Questions d'épistémologie théologique et philosophique, Saint-Maur 1997, s. 223-232.
} 
da na swój sposób, ważnej pomocy w lepszym poznaniu człowieka, a równocześnie są one impulsem do lepszego określenia sensu prawd objawionych, które odnoszą się do człowieka. Wszystko to, co dotyczy człowieka, interesuje teologię, ponieważ nauka o objawieniu, jak samo objawienie, służy ludziom ${ }^{11}$. Stanowisko teologa wobec różnych dyscyplin naukowych powinno być zarazem $\mathrm{k} \mathrm{ry}$ t y c z n e, ponieważ teologia nie może zaakceptować, by nawet naukowo osiagane rezultaty stawały się jedynym wyznacznikiem rozumienia jej treści. W podejściu krytycznym nie chodzi więc o to, by wydawać niekorzystne oceny tego, co dostarczają nauki antropologiczne, ale o to, by wiedza, której one dostarczaja, była poddana rygorystycznej analizie i by dokonywano właściwej oceny jakości jej wyników. Spójrzmy na niektóre aspekty tej propozycji.

Nauki o człowieku pomagają nam poznać lepiej człowieka. Nie oznacza to, że same z siebie determinują znajomość natury ludzkiej. Wszystkie te nauki mają charakter eksperymentalny i chwytają tylko pewne wybrane aspekty badanej rzeczywistości, dlatego też widzą one człowieka w określonym i ograniczonym kontekście. By służyć poznaniu natury ludzkiej, potrzebują pomocy ze strony filozofii, która jako jedyna pozwala rozumowi uchwycić trwałe wartości.

Nauki o człowieku są inspiracją. Takie ujęcie jest właściwe, ponieważ uwypukla typ relacji, jaki powinien zostać nawiązany między tymi dyscyplinami i teologią. Chodzi o obszary bardzo odrębne, a w konsekwencji i o własne metody, którymi posługują się różne dyscypliny naukowe. Teologia pozwoli, by nauki o człowieku zadawały jej pytania, ale ma ona udzielać na nie swoich odpowiedzi przede wszystkim w świetle słowa Bożego. Te pytania mogą być bardzo wartościowe, ponieważ doprowadzą teologię do reagowania w sposób autonomiczny, do analizowania nowych aspektów problemu ludzkiego i ukazywania znaczenia tajemnicy zbawienia w odniesieniu do nowych wyzwań eklezjalnych i kulturowych.

Nauki antropologiczne domagają się uważnej analizy krytycznej. Przede wszystkim dlatego że stanowią pole, na którym założenia filozoficzne i w ogóle warunki społeczno-kulturowe, w których żyje człowiek, odgrywają bardzo ważną rolę; następnie, dlatego że niektórzy specjaliści z tych dziedzin mają tendencję do zapominania o ograniczeniach ich własnej dyscypliny i do zbyt łatwego uogólniania konkluzji, tracąc $\mathrm{z}$ oczu inne dziedziny nauki zajmujące się człowiekiem. Socjolog, dla którego każda rzeczywistość jest socjologia, i psycholog, dla którego wszystko wyjaśnia się za pośrednictwem psychoanalizy, nie są rzadkimi przypadkami w dzisiejszym świecie. Nauki antropologiczne - w końcu - domagają się analizy krytycznej także z tej racji, że nie tylko są naukami rozwijającymi się, ale one same nie są jeszcze skonsolidowane metodycznie. Konkluzje, do

${ }^{11}$ Por. P. Coda, Teo-logia. La Parola di Dio nelle parole dell'uomo. Epistemologia e metodologia teologica, Roma 1997, s. 247-250. 
których się w nich dochodzi, są tego odzwierciedleniem. Często ci sami socjologowie wyprowadzają $\mathrm{z}$ tych samych danych $\mathrm{w}$ różnych okolicznościach bardzo zróżnicowane wnioski.

Zadanie jest więc bardzo złożone. Czy teolog może podjąć je samodzielnie? Czy musi stać się, za każdym razem, socjologiem, psychologiem, etnologiem, historykiem religii? Oczywiście, że nie. Powraca tutaj potrzeba dialogu, o którym trafnie wypowiedział się Sobór Watykański II w konstytucji Gaudium et spes

Niechaj ci, którzy oddają się badaniom teologicznym w seminariach i na uniwersytetach, jednocząc siły i koncepcje, starają się współdziałać z przedstawicielami innych dyscyplin naukowych. Niech dociekanie teologiczne zmierza do głębokiego poznania prawdy objawionej i jednocześnie nie zaniedbuje łączności ze współczesnościa, aby mogło ono pomóc ludziom wykształconym w różnych dyscyplinach naukowych w osiagnięciu pełniejszego poznania wiary (nr 62).

Jest jeszcze wiele do zrobienia $w$ ramach tego wskazania, a zwłaszcza w punkcie wyjścia należy pamiętać, że ten dialog jest wymagający i równocześnie niełatwy: „Mimo iż Kościół bardzo się przyczynił do rozwoju kultury, z doświadczenia jednak wiadomo, że harmonijne łączenie kultury z nauczaniem chrześcijańskim, z pewnych występujących w konkretnych sytuacjach przyczyn, nie zawsze przebiega bez zakłóceń" (nr 62).

Nie jest to zaproszenie do pogodzenia się $\mathrm{z}$ istniejącą sytuacją lub do kompromisu. Przekonania wypływające $z$ wiary mówią, że musimy dążyć do przezwyciężenia trudności z cierpliwością, ale także z wytrwałością. Sobór Watykański I w konstytucji Dei Filius naucza: „Mimo że w istocie wiara przewyższa rozum, to jednak nigdy nie może istnieć rzeczywista niezgodność pomiędzy wiarą i rozumem, gdyż ten sam Bóg, który objawia tajemnice i wlewa wiarę, wzniecił też światło rozumu w duszy ludzkiej; Bóg zaś nie może zaprzeczać samemu sobie, ani prawda nie może nigdy sprzeciwiać się innej prawdzie" (rozdz. 4). Ta wypowiedź soborowa jest zachętą do dynamizmu poznawczego ożywianego przez nadzieję pokonania pojawiających się trudności.

Nauki o człowieku mają niewątpliwe znaczenie dla teologii, ale właściwe podejście do tych nauk i służba, jaką mogą one okazać teologii, wymagają interwencji ze strony filozofii ${ }^{12}$. Taki jest paradoks aktualnej sytuacji. Nauki o człowieku, które - w oczach niektórych - dystansują od filozofii i czynią ją zbędną, nieustannie odwołują się do interwencji filozofii. To jest fakt, który powinien w znacznie większym stopniu zwrócić naszą uwagę, a tym samym spotkać się z odpowiednią reakcją zwłaszcza ze strony filozofów chrześcijańskich.

$* * *$

${ }^{12}$ Por. G. Cottier, Les chemins de la raison, dz. cyt., s. 233-254. 
Już Arystoteles wiedział, że metoda jest czymś więcej niż techniką naukową oraz uporządkowanym i zaplanowanym sposobem postępowania, aby dojść do uzasadnionego i uporządkowanego poznania określonej dziedziny rzeczywistości. Drogą do prawdy może być tylko sama prawda. Metoda jest więc refleksją nad droga, która postępuje sama prawda wraz z nami, oraz nad stopniowo wyłaniającym się celem, do którego ma nas doprowadzić. Zagadnienie to jest szczególnie widoczne w teologii, która podejmuje refleksję naukową nad prawdą Bożą, która jest dla człowieka prawdą zbawczą. Na niektóre aspekty tej problematyki chcieliśmy tutaj zwrócić uwagę.

\section{Some Challenges Concerning the Method of Theology}

\section{Summary}

This study focuses on two issues, namely: the issue of the contemplative character of theology (it deals with the nature of theology), and the question of how other academic disciplines especially anthropological ones - may contribute to theology. The latter is an attempt to point out certain possible interdisciplinary applications of theology, and to open to the subject of its study and to the formulated proposals concerning particularly understanding of man and his life on earth. The issue of a contemplative character of theology, deeply rooted in its own history, has to struggle today with two phenomena: anthropological reductionism and the preference given to action. The question then arises: why cannot such tendencies be accepted uncritically? Contemporary theology faces a serious challenge because it has to include in its study a positive contribution made by humanities for understanding of man. However, a question may be asked: how to take advantage of the achievements of these disciplines so that the theological reflection may preserve its specific character and serve a deeper understanding of faith and its essence.

\section{Keywords}

theology, method, contemplation, anthropology, action, humanities

\section{Slowa kluczowe}

teologia, metoda, kontemplacja, antropologia, działanie, nauki humanistyczne

\section{Bibliografia}

Anzelm, Liber de fide Trinitatis et de incarnatione Verbi contra blasphemias Ruzelini sive Roscelini: PL 158, 259-284.

Balthasar H.U. von, Kim jest chrześcijanin?, tłum. F. Wycisk, Paris 1971.

Chapelle A., À l'école de la théologie, Bruxelles 2013.

Coda P., Teo-logia. La Parola di Dio nelle parole dell'uomo. Epistemologia e metodologia teologica, Roma 1997.

Cottier G., Les chemins de la raison. Questions d'épistémologie théologique et philosophique, Saint-Maur 1997. 
Jossua J.P., Peut-on parler de Dieu?, Genève 2006.

Królikowski J., Teologia między ortodoksja i ortopraksja, w: Tożsamość teologii, red. A. Anderwald, T. Dola, M. Rusecki, Opole 2010, s. 187-201.

Latourelle R., Théologie de la révélation, Paris 1969.

Pattaro G., Bartolomei M.C., Gallas A., La svolta antropologica. Un momento forte della teologia contemporanea, Bologna 1991.

Tomasz z Akwinu, In Symbolum Apostolorum scilicet "Credo in Deum" expositio. S. Thomae Aquinatis Opuscula theologica, vol. 2: De re spirituali, a cura et studio R.M. Spiazzi, Taurini - Romae 1954, s. 191-217. 